FILOZOFIA

Roč. 75,2020 , č. 7

DOI: https://doi.org/10.31577/filozofia.2020.75.7.7

\title{
ODPUSTENIE V POLITIKE: REALITA ALEBO ILÚZIA?
}

\author{
DAGMAR SMREKOVÁ, Filozofický ústav Slovenskej akadémie vied, Bratislava, SR
}

SMREKOVÁ, D.: Forgiveness in Politics: Reality or Illusion? FILOZOFIA, 75, 2020, No 7, pp. $596-611$

\begin{abstract}
There are opposing views on the question of whether forgiveness makes sense as a political act. The main focus of the study is the debate about forgiveness among francophone philosophers. Some authors agree with the idea of transferring forgiveness to the domain of politics, while others have a hesitant or even negative attitude. The aim of the article is to examine the main arguments for and against each position and to find out which of the opposing views provides stronger arguments, or whether there is another defensible alternative. A key point in the dispute over forgiveness in politics is the question of whether forgiveness can be used as a strategic political tool, and, at the same time, maintain its meaning, its moral value. With regard to the resolution of this dispute, the author of the article questions the possibility of mixing two different levels: the political-legal level (to which "the politics of forgiveness" is linked) and the ethical level, which is the actual domain of forgiveness as a non-political and non-legal relationship. According to the author, thinking about forgiveness as a political tool is based on wrong reasoning. It presupposes the possibility of playing on two tables at the same time: pursuing the collective, political purpose of forgiveness, and at the same time wanting to preserve its character as a personal relationship between the offended and the offender, the victim, and the perpetrator. The author defends the view that forgiveness cannot be politically institutionalized or confused with terms belonging to the political-legal domain (such as political reconciliation or amnesty) unless its meaning is devalued.
\end{abstract}

Keywords: Forgiveness - Politics of forgiveness - Reconciliation - Transitional Justice - Vladimir Jankélévitch - Jacques Derrida - Paul Ricœur - Pierre Hazan - Sandrine Lefranc

\section{Úvod}

Otázka odpustenia v politike sa prvýkrát objavila po druhej svetovej vojne v súvislosti s úsilím vyrovnat' sa so zločinmi proti l'udskosti, ktoré znamenajú bezprecedentné popretie najzákladnejších l'udských práv. Spojenie odpustenia s politikou je na prvý pohl'ad prekvapivé. Odpustenie a politika sú pôvodne dva navzájom celkom odlišné poriadky, dva cudzorodé svety. Odpustenie je osobná, vel'mi intímna udalost', odohrá- 
vajúca sa medzi dvoma bytost’ami (medzi urazeným a urážajúcim v kontexte medzil'udských vzt'ahov, medzi hriešnikom a Bohom v prípade náboženského rozmeru odpustenia). Ide o slobodné a vo svojej autentickej podobe spontánne a nezištné gesto jednotlivca adresované druhému, ktoré nemožno vynútit' nijakou vonkajšou inštanciou. ${ }^{1}$ Gesto odpustenia ustanovuje určitú rovnost' medzi odpúšt’ajúcim a tým, kto mu ublíżil. Nie je prejavom moci nad druhým a obmedzenia jeho slobody, no ani zárukou, že vinník sa polepší a nezotrvá nad'alej vo svojej nenapravitel'nosti. Naproti tomu politika sa vzt’ahuje na výkon moci v organizovanej spoločnosti v záujme dosiahnutia určitých ciel'ov; je teda sférou „obmedzenej slobody“ (Lévy 1993, 27). Politický poriadok súvisí so siet'ou inštitúcií, ktoré sú nevyhnutné na regulovanie vzt'ahov moci a podriadenosti, aby sa spoločnost' udržala pohromade. Preto sa odpustenie zo svojej podstaty vzd'al'uje politike. ${ }^{2}$

Odpustenie ako politický problém sa v morálno-filozofických debatách objavilo v súvislosti s realitou absolútneho zla, s uznaním neodpustitel’ného, ktorého symbolom sa stal holokaust. Paradoxne práve fakt existencie neodpustitel'ného (nielen v po-

\footnotetext{
${ }^{1}$ Objasnit' pojem odpustenia, preniknút' k jeho podstate, je filozofická otázka. Podl’a H. Arendtovej odpustenie, tento pôvodne náboženský pojem, má miesto aj v oblasti l’udských záležitostí - z dôvodu nezvratnosti dôsledkov konania, ktoré by bez odpustenia $z$ človeka navždy urobili obet' toho, čo raz vykonal (pozri Arendt 2012, 251). Z povojnových myslitel’ov prvotnú zásluhu na precizovaní odpustenia ako filozofického pojmu má V. Jankélévitch, ktorý „pravé“ odpustenie zakotvil v „hyperbolickej etike“, etike presadzujúcej sa nad rámec záväzkov a noriem, pričom vyzdvihol tri jeho základné rysy: ide o udalost', ktorá prichádza v určitom okamihu; ide o osobný vzt’ah, kde jedna osoba odpúšt'a druhej; ide o bezdôvodný a bezodplatný dar urazeného tomu, kto ho urazil (Jankélévitch 1967, 12;1996, 10). Na Arendtovej myšlienku neponechat' vinníka spútaného dôsledkami jeho konania nadviazal Ricœur. Ten však podstatu odpustenia videl v možnosti „oddelit' konajúceho od jeho činu“" (Ricœur 2000, 637), a nielen od dôsledkov tohto činu. Veril totiž, že schopnosti morálneho subjektu sa nevyčerpávajú jeho zlými skutkami, pretože jeho potenciál je väčší, ako ukazujú jeho viny a pochybenia.

${ }^{2}$ Debata, o ktorú sa opiera tento článok, vychádza z predpokladu, že politiku v zásade určujú mocenské vzt'ahy. Prirodzene, politiku možno chápat' aj širšie - a to cez koncepciu občianstva a verejného (politického) života - a v tomto rámci uchopit' odpustenie ako svojou povahou politický fenomén. Tak ho určuje H. Arendtová, ktorá o odpustení uvažuje v súvislosti s konaním, z jej hl’adiska ústredným politickým pojmom. Schopnost' vykúpit' sa z nezvratnosti dôsledkov vyplývajúcich z nepredvídatel’nosti konania podl'a Arendtovej závisí od spolubytia s inými a s rešpektom voči iným v širokej oblasti l'udských záležitostí. Arendtová osobitne vyzdvihuje potenciál odpustenia zachovat' slobodu konajúcich a vymanit' l'udské vzt’ahy zo zajatia minulosti, ktorá ich rozkladá. Naproti tomu Jankélévitch, ku ktorého koncepcii odpustenia sa prihlasujeme, nezdiel'a optimizmus spojený so začlenením odpustenia do politickej roviny. Podl'a neho napriek všemocnosti odpustenia existuje hranica, ktorá je pre odpustenie neprekročitel'ná, a to bez ohl'adu na jeho možný politický, spoločenský či psychologický prínos - touto hranicou sú zločiny proti l'udskosti, právne kvalifikované ako nepremlčatel'né. Jankélévitch definuje odpustenie ako osobný (intersubjektívny) vzt’ah, a nie ako vzt'ah politický. V texte sa usilujeme domýšl'at' konzekvencie tohto chápania odpustenia v súvislosti s politikou.
} 
dobe zločinu holokaustu, ale aj nových vojnových zločinov, zločinov genocídy a etnických čistiek, masívneho porušovania l’udských práv, pedofilie...) pohýna politikov k tomu, aby siahali po ,jazyku“ odpustenia. Robia to s vedomím, že na určité zločiny je každá spravodlivost' krátka, pretože pokial' ide o charakter týchto zločinov a ich dôsledky pre obete, tieto zločiny sú doslova nevykúpitel'né. Otázka odpustenia sa totiž neohlasuje tam, kde ide o malé prehrešky a neúmyselné či ospravedlnitel'né faux pas. Sebaobviňovanie, l'útost', ospravedlňovanie i prosby o odpustenie sa objavujú tam, kde existuje vážna vina, neodpustitel’né zlo. Mnohí autori na čele s Jankélévitchom však možnost' odpustenia zavrhli v momente, ked' sa táto otázka objavila v právnopolitickom kontexte, ktorý sa týkal nacistických vojnových zločinov a zločinov holokaustu. Zamietli ju nielen z politicko-právneho hl'adiska, pre právnu nepremlčatelnost' týchto zločinov, ale aj z morálnych dôvodov - pre metafyzické zlo v nich obsiahnuté, čiže pre utrpenie špecifického druhu, zrodené z vedomého úmyslu odňat' časti l'udského rodu právo existovat', popriet' v druhom l'udskost' človeka. V Jankélévitchových očiach po holokauste neexistuje nijaký, ani morálny dôvod odpustit' tieto zločiny, a to nielen pre ich extrémne nel'udský charakter a absenciu l'útosti zo strany páchatel'ov, ale aj preto, že ich obete, ktoré jediné by mali právo odpustit', sú mŕtve: „Odpustenie zomrelo v táboroch smrti“(Jankélévitch 1986, 50). Iní autori, ako Derrida, sa naopak usilovali premysliet' možnost' odpustenia práve v dejinnej situácii, ktorá ho znemožnila; pokúšali sa presvedčit', že zmysel odpustenia ako nadprávneho aktu sa napíňa v odpustení neodpustitel'ného. Totiž z určitého hl'adiska ${ }^{3}$ sa odpustenie uznáva za „čisté“ len v jeho nepodmienenom formáte - bez ohl'adu na to, či na zločin existuje adekvátna odpoved' v podobe primeraného trestu (teda či zločin je odpykatel'ný) a či vinník požiadal o odpustenie. Pre Derridu jedine neodpustitel'né je naozajstným testom toho, či to s odpustením myslíme úprimne. „Odpustenie má svoj zmysel (pokial' si skutočne má zachovat' zmysel, čo nie je to isté), nachádza svoju možnost' odpustit' práve tam, kde je vyzvané robit' ne-možné a odpúšt'at' neodpustitel'né“ (Derrida 2005, 30 - 31). Derrida zároveň jednoznačne vylúčil možnost' založit právo alebo politiku na odpustení. A to jednak preto, že aj v šlachetnom geste toho, kto ponúka zmierenie alebo amnestiu, tušil strategické či politické kalkulovanie; a jednak preto, že právno-politické prepáčenie trestu, čo je inštitucionálny akt, nie je to isté čo odpustenie v jeho medziosobnej dimenzii. „Akonáhle do toho vstúpi tretí, môžeme ešte hovorit' o amnestii, zmierení, náprave škôd, atd'. Ale nie v prísnom zmysle slova o odpustení“ (Derrida 2001, 117; čes. 2003, 112).

\footnotetext{
${ }^{3}$ Ide o hl'adisko inšpirujúce sa tým rozmerom abrahámovskej tradície odpustenia, ktorý zdôrazňuje myšlienku bezmedzného, nepodmieneného odpustenia, udeleného vinníkovi bez akejkol'vek protihodnoty, na rozdiel od odpustenia spájaného s podmienkami, ako l'útost', uznanie viny, prosba o odpustenie.
} 
Napriek týmto námietkam (teoretikom odpustenia dobre známym) sa nedá prehliadnut' fakt, že termíny vina, lútost', ospravedlnenie, zmierenie (ktoré predstavujú pojmové „okolie“ odpustenia, hoci sú významovo rozdielne), sa v politike udomácnili. Paradoxne zaznievajú často z úst tých politikov, ktorí nemajú nič spoločné s minulými zločinmi, no sú ochotní prevziat' za ne čast' politickej zodpovednosti. Ba dokonca v ostatných desat'ročiach sme svedkami znásobovania týchto prejavov, a to nielen v cudzích krajinách a na iných kontinentoch, ale aj u nás. ${ }^{4}$

Úsilie včlenit' odpustenie do roviny politiky a uznat' ho za legitímne politické gesto vyvoláva celý rad otázok. Tá klúčová znie: Je možné niečo také ako odpustenie, teda pojem a akt, ktorý sa pôvodne týka roviny vzt’ahov „tvárou v tvár“, preniest' do politickej a inštitucionálnej oblasti bez rizika, že to zdeformuje jeho pôvodný zmysel? S touto otázkou súvisia d’alšie: Existuje nadosobná kolektívna inštancia, ktorá by bola oprávnená odpustit' povedzme v prípadoch, ked' sa politik v mene svojho národa verejne ospravedlňuje inému národu za kolektívne zločiny spáchané na príslušníkoch tohto národa $\mathrm{v}$ minulosti, alebo ked' sa pred svojím vlastným národom kajá za zločiny svojich politických predchodcov? A ako toto premiestnenie rétoriky vlastnej odpusteniu na úroveň politiky vnímajú obete? Dokážu preživšie obete kolektívne páchaného násilia a masívneho potláčania ich l’udských práv tieto verejné prejavy l'útosti a ospravedlnenia z úst politikov akceptovat? Dá sa na tomto základe povzniest' ponad osobne prežitú potupu a gestom vel'kodušného omilostenia kajúcnika, vystupujúceho v mene pôvodcov zločinov, znovu nadobudnút' svoju zhanobenú čest' a dôstojnost'? Neriskujeme, že začlenením do politiky sa odpustenie zmení na frašku? Nie je predstava odpustenia ako kolektívneho politického gesta čírou fikciou? Nemá pravdu Derrida, ked' naznačuje, že prenesenie jazyka odpustenia s jeho duchovnou dimenziou z osobnej sféry do verejného a politického priestoru môže evokovat' niečo iné, než za čo sa vydáva? Ved' verejný rituál lútosti, navonok signalizujúci zmenu postoja k minulým zločinom a prejavený za účelom očakávaného odpustenia, oddel'uje len tenká hranica od druhu výhodného výmenného obchodu. No predsa len je tu pochybnost': dá sa s istotou tvrdit', že odpustenie nemá s oblast'ou politiky nič spoločné, že nemá na politiku, ktorá sa usiluje o normalizáciu vzt'ahov po prekonaných konfliktoch, nijaký účinok?

\footnotetext{
${ }^{4}$ Najaktuálnejší príklad: Súčasný predseda Národnej rady SR Boris Kollár (Sme rodina) sa oficiálne ospravedlnil Gréckokatolíckej cirkvi za jej protizákonné a nedemokratické postavenie mimo zákona pred sedemdesiatymi rokmi. Kollár sa ospravedlnil aj všetkým občanom, ktorých základné práva boli v tom čase významne poškodené štátnou mocou. Pozri na: https://www.webnoviny.sk/predseda-parlamentu-kollar-sa-ospravedlnil-greckokatolickej-cirkvi-za-nepravosti-z-minulosti/ (Navštívené: 25. 5. 2020).
} 
$\mathrm{Na}$ otázku, či odpustenie má zmysel ako politické gesto, dodnes nie sú jednotné názory. V rámci súčasnej filozofickej debaty o odpustení medzi frankofónnymi autormi ${ }^{5}$ čast’ filozofov súhlasí s projektovaním symbolickej „ekonómie“ odpustenia do oblasti politiky. Tí najodvážnejší sa neboja pripísat' odpusteniu vlastnost' užitočného politického a diplomatického nástroja normalizácie vzt'ahov po ukončení politického konfliktu - ked’že v uplatnení trestnej spravodlivosti tušia možný zdroj nového násilia. Vyzývajú preto na odhodenie predsudkov, ktoré odpustenie uzatvárajú do rámca intímneho interpersonálneho vzt’ahu. Na opačnom póle názorového spektra stoja tí, ktorí váhajú, respektíve odmietajú priznat' odpusteniu v politike legitímne miesto najmä z obavy, že presadením odpustenia do pôdy, ktorá zahŕňa ako svoje nevyhnutné zložky násilie a inštrumentálny prístup k riešeniu sporov, sa prekrúti jeho vnútorná hodnota. Ba dokonca vyjadrujú pochybnost', či sa odpustenie v politických a sociálnych zmierovacích procesoch po kolektívne páchaných zločinoch nestáva prostriedkom na posvätenie beztrestnosti, a teda porušením demokratického princípu rovnosti pred zákonom.

S. Lefrancová - ktorá termín politiky odpustenia použila ako názov svojej rozsiahlej sociologicko-filozofickej práce, venovanej problematike hl'adania východísk zo situácií politického násilia (Lefranc 2002) -, naznačuje, že túto otázku treba brat' vážne. Dôvod je jednoduchý: rétorika odpustenia v politike existuje, ba dokonca sa stáva dominantnou podobou debát o spravodlivosti, na základe ktorých sa nové demokracie pokúšajú obnovit' svoj vzt'ah ku konfliktnej minulosti. Zámerom článku je preskúmat' argumenty pro aj kontra, objavujúce sa v debate o odpustení ako o politickom akte, a zistit', ktorá z protikladných pozícií argumentačne obstojí, respektíve či v porovnaní s nimi existuje aj iná obhájitel'ná alternatíva. Kl'účovým bodom sporu o odpustenie v politike je otázka, či možno využit' odpustenie ako strategický politický nástroj, a zároveň zachovat' jeho zmysel, jeho morálnu hodnotu.

\section{Odpustenie ako politický nástroj}

Myšlienka, že odpustenie je dôležitý politický nástroj pri hladaní východiska z konfliktných situácií vnútri štátu alebo medzi štátmi, nie je nijako samozrejmá. Väčšinu l’udí táto myšlienka pretavená do praxe vyrušuje. Nie je im napríklad celkom jasné, prečo by sa na základe politického rozhodnutia malo en bloc odpúšt’at' vinníkom, ktorí

\footnotetext{
${ }^{5} \mathrm{Na}$ debatu frankofónnych autorov o odpustení sa tu sústred'ujeme okrem iného preto, že impulz na otvorenie a rozvinutie tejto debaty na pôde filozofie po druhej svetovej vojne vyšiel z textov V. Jankélévitcha Imprescriptible (1986) a Le pardon (1967), ako aj z následnej polemiky Derridu $\mathrm{s}$ Jankélévitchom a $\mathrm{z}$ úvah Ricœura. Práce týchto autorov na tému odpustenia možno dnes pokladat' za referenčné nielen vo francúzskom, ale aj v medzinárodnom kontexte. (Porovnaj napríklad zborník z medzinárodnej konferencie Vladimir Jankélévitch and the Question of Forgiveness, ed. A. Udoff, 2013).
} 
o odpustenie ani nežiadali (tzv. generálny pardon). ${ }^{6} \mathrm{~A}$ ak majú l'udia pochybnosti o správnosti politiky odpustenia povedzme $\mathrm{v}$ prípadoch odpustenia dlhov, zrušenia exekúcií či uplatnenia inštitútu politickej amnestie (ktorý umožňuje prezidentovi či prezidentke hromadné odpustenie trestov za určité trestné činy), z akých dôvodov by mali mat' pochopenie pre takúto politiku v súvislosti so závažnými kolektívne páchanými zločinmi? A akej reprezentatívnej autorite (politickej, inštitucionálnej) by malo byt' priznané právo odpustit', prípadne vyzývat' obete kolektívnych zločinov na odpustenie vinníkom, alebo toto odpustenie od nich vyžadovat' povedzme $\mathrm{z}$ hl'adiska „Vyššieho“, politického záujmu - v mene zjednotenia spoločnosti rozdelenej minulými neprávost’ami a utrpením? A predsa čast' morálnych filozofov prinajmenšom zaváha $\mathrm{v}$ momente, ked' by mali každú možnost' odpustenia $\mathrm{v}$ politike definitívne vylúčit'. Venujme preto najprv pozornost' logike uvažovania a argumentom tých autorov, ktorí sú presvedčení, že odpustenie má nielen osobnú dimenziu, ale aj významné miesto $\mathrm{v}$ registri politických nástrojov.

Podla P. Hazana sa na prvý pohl'ad nič nejaví vo väčšom protiklade ako praktická politika a odpustenie, no dá sa ukázat' opak: že „odpustenie je politický a diplomatický nástroj, ktorý sa využíva tak na medzištátne, ako aj na vnútropolitické ciele“ (Hazan 2012, 82). Hazan inšpirovaný realistickým prúdom medzinárodnej politiky (kde politika sa chápe ako doména konfliktu) verí, že ciel’om odpustenia v politike je „prostredníctvom uznania minulých zločinov a verejného vyjadrenia pokánia pozitívne transformovat' vzt'ah so štátom alebo so spoločenstvom, ktoré sa stali obet'ou týchto zločinov“ (Hazan 2012, 82). Hazan pritom neopomína výstrahu Derridu, podla ktorého znásobenie scén lútosti na politickej scéne často so sebou nesie pretvárku, teatrálnost' či kalkulovanie. No napriek tomu neváha priznat' prejavom l'útosti (ako predpokladu odpustenia) v politike legitímne miesto. Spolieha sa na to, že „pomery v politike sú $\mathrm{v}$ zásade určované mocenskými vzt'ahmi, zatial' čo lútost' ruší túto logiku konfrontácie. Zavádza prvok, ktorý pozastavuje silový vzt’ah. Mení podmienky diskusie medzi stranami a práve táto rekonfigurácia vzt’ahu prináša výhody. Strana, ktorá prostredníctvom lútosti verejne priznala svoju vinu, koná zdanlivo proti svojim záujmom. Tým, že sa ocitla v pozícii slabosti, ked’ vzala svet za svedka, potvrdzuje poškodenému štátu alebo spoločenstvu, že už nie je tá istá, že odteraz je iná, odpútaná od zločinu, ktorý odsudzuje a ktorý odteraz na seba preberá ako súčast' svojho dedičstva. Týmto vyzýva poškodenú stranu, aby prehodnotila svoj vzt’ah. Jej prestíž a jej

\footnotetext{
${ }^{6}$ Napríklad z prieskumu agentúry Stem / Mark pre Českú asociáciu veritel’ov, zverejneného 18. 9. 2019 na Novinky.cz, vyplýva, že Česi nechcú odpúšt’at' dlžníkom dlhy, ale dali by im možnost' si ich odpracovat'. Pomoc zo strany štátu by občania poskytli l'ud'om, ktorí sa do dlhovej pasce dostali za nešt’astných okolností, ako je dlhodobá choroba alebo strata zamestnania. Treba podotknút', že prieskum sa konal zhruba pol roka pred svetovou pandémiou spôsobenou koronavírusom Covid 19, ktorá zásadne zmenila dlhové pomery domácností.
} 
legitímnost' vychádzajú posilnené týmto aktom l'útosti, ak je dobre vykonaný“ (Hazan 2012, 82). P. Hazan nie je jediný, kto vsádza na význam odpustenia ako politického nástroja. G. Causse sa usiluje ukázat', že odpustenie prekročením prahu individuálneho náboženského vedomia smerom $\mathrm{k}$ politike od pät'desiatych rokov minulého storočia postupne nadobúda nový inštitucionálny zmysel; a že práve v inštitucionálnych formách odpustenia možno znovu nájst' zabudnuté základné prvky našich tradícií odpustenia. Causse dokonca tvrdí, že aj ked' sa odpustenie neredukuje na jeho inštitucionálnu figúru, „bez odpustenia by inštitúcie nemohli uzriet' svetlo sveta ani pretrvat““ (Causse 2016, 260). Obe tieto teoretické vízie sa opierajú o konkrétne príklady z nedávnych dejín aj zo súčasnej politickej praxe štátov alebo spoločností, ktoré hl'adajú východisko zo situácií násilia. Empirické hl’adisko im má poskytnút' účinný argument na potvrdenie tézy o existencii politického, respektíve inštitucionálneho odpustenia.

Jedným z prejavov odpustenia v politike má byt' jeho využitie v podobe , podmienky návratu $k$ štátnej zvrchovanosti “(Hazan 2012, 84) a ako nástroja ustanovenia diplomatických vzt'ahov bezprostredne po druhej svetovej vojne (Causse 2016, 258). Totiž podmienkou umožňujúcou návrat Nemecka k úplnej zvrchovanosti a ustanovenie diplomatických vzt'ahov s mladým izraelským štátom bolo uznanie zodpovednosti za utrpenie Židov počas vojny a uhradenie vojnových reparácií zo strany Nemcov. Pravda, proti spojeniu reparácií s odpustením treba namietnut', že stavia na mylnom predpoklade, akoby prijatie odškodnenia stranou, ktorá utrpela ujmu, bolo gestom odpustenia.

Inou formou pokladanou za uplatnenie odpustenia v politike má byt' jeho využitie ako nástroja normalizácie medzištátnych vzt'ahov. Táto predstava sa odvoláva na známe gesto kancelára Willyho Brandta, ktorý v roku 1970 pri príležitosti podpisu nemecko-pol'skej zmluvy vo Varšave pokl’akol pred pamätníkom hrdinov židovského geta, a hoci sám nevinný, symbolickým gestom pokánia prevzal pred celým svetom na svoje plecia bremeno viny za zločiny nacistického Nemecka. Hazan toto gesto vníma ako prosbu o odpustenie za nacistické zločiny. „Willy Brandt symbolicky nakreslil deliacu čiaru medzi minulost'ou a prítomnost'ou a vytvoril novú identitu Nemecka tým, že celú jeho temnú minulost' prevzal na seba. Táto identita po odpustení spriehl'adnila vzt'ahy k minulosti a od tej doby ul'ahčila politické a ekonomické kontakty s krajinami, ktoré trpeli pod nacizmom“ (Hazan 2012, 85). Tu však treba spresnit', že gesto ospravedlnenia zo strany reprezentanta krajiny bývalého agresora je síce vedené „logikou“ odpustenia (totiž ospravedlnenie je súčast’ou prosby o odpustenie, ktorá prináleží agresorovi), no odpoved’ou na toto gesto, akokol'vek úprimné, nemôže byt' odpustenie. Odpustenie prichádza len od obete, od urazeného. Pri politicky prejavenom akte ospravedlnenia je však sporný adresát - nie sú ním priame obete, ale spoločenstvo ako celok, národ ako taký, minulé aj prítomné generácie...; a preto rovnako 
spornou a t'ažko zodpovedatel'nou zostáva otázka Kto má odpustit?, najmä ked' obete sú mítve.

A do tretice uved'me ešte jeden zo série príkladov, ktoré z hl'adiska Hazana aj Caussa majú slúžit’ ako argument potvrdzujúci politický vplyv odpustenia. Ide o domnelé využitie odpustenia ako nástroja občianskeho zmierenia (Hazan 2012, 87), respektíve dosiahnutia jednoty spoločnosti prostredníctvom svedectva a pozdvihnutia obetí (Causse 2016, 262 - 263). Obaja autori v tejto súvislosti narážajú na fakt, že v devät'desiatych rokoch sa odpustenie stalo integrálnou súčast'ou nástrojov prechodovej spravodlivosti ${ }^{7}$ uplatňovanej $\mathrm{v}$ štátoch, ktoré sa vymanili $\mathrm{z}$ obdobia masívneho potláčania ludských práv. Za jeden zo spôsobov využitia odpustenia v prospech zmierenia pokladajú ustanovenie Komisie pre pravdu a zmierenie v Juhoafrickej republike a inde s ich nástrojmi, akými boli uznanie statusu obete, odstránenie závoja mlčania o zločinných udalostiach prostredníctvom osobných výpovedí obetí, odškodnenie obetí a podmienečná amnestia pre vinníkov za predpokladu, že títo uznajú svoju vinu na zločinoch spojených s režimom apartheidu.

Problém so začlenením odpustenia do politiky tkvie v tom, že strategická dimenzia odpustenia by nemala byt' viditel'ná, ak sa tento nástroj nemá chápat' len ako cynické kalkulovanie, zbavené akejkol'vek morálnej hodnoty. Z hl'adiska P. Hazana otázka stojí takto: „Aké je najoptimálnejšie riadenie odpustenia, ked' vieme, že l'útost', ak by sa javila iba ako zištná, stráca svoju hodnotu?“ (Hazan 2012, 89) Odpoved” nachádza v dvoch rozdielnych príkladoch politického riadenia odpustenia. Jedným je činnost' zmienenej Komisie pre pravdu a zmierenie $\mathrm{v}$ Juhoafrickej republike: Z obavy, že by sa žiadosti páchatel'ov zločinov apartheidu o odpustenie obmedzili na „komédiu ospravedlnenia“, páchatelia získali amnestiu výmenou za priznanie, avšak bez nevyhnutnosti ol'utovat' svoj čin. Bremeno odpustenia sa tak prenieslo z páchatel'ov (ktorí sa nemuseli ospravedlňovat') na rodiny obetí apartheidu. Tento transfer odpustenia na obete, sám osebe morálne problematický, bol pre mnohé obete neprija-

\footnotetext{
${ }^{7}$ Zaužívaný termín prechodová spravodlivost'(fr. la justice transitionnelle; angl. transitional justice, korektný slovenský ekvivalent by mohol byt' spravodlivost' prechodného obdobia) sa použiva na označenie všetkých opatrení, ktoré politický režim, zavedený bezprostredne po ozbrojenom konflikte alebo po politickej kríze, využil na riešenie masového násilia a / alebo systematického porušovania l’udských práv, aby ul'ahčil zmierenie a podporil nastolenie právneho štátu a demokracie. Ide o vynájdenie nových postupov tam, kde na riešenie konfliktov nepostačovali bežné súdne inštitúcie a trestná spravodlivost'. Detailnejšie pozri Turgls $(2015,333$ - 342) V rámci súdnych alebo mimosúdnych konaní sa využíva aj restorativna (obnovujúca) spravodlivost' (fr. la justice restauratrice, angl. restorative justice), ktorá sa netýka štátu, ale obetí a páchatel'ov. Ciel'om tejto formy spravodlivosti je poskytnút' zadost'učinenie obetiam (najmä morálne a emocionálne) a priviest' páchatel'ov k tomu, aby si uvedomili zodpovednost' za svoje zločiny a prejavili empatiu voči obetiam, $\mathrm{s}$ konečným ciel'om prispiet' $\mathrm{k}$ zachovaniu mieru a bezpečnosti $\mathrm{v}$ spoločnosti. (K rozdielom medzi trestnou a restoratívnou spravodlivost'ou detailnejšie pozri Lecomte $(2012,223$ - 235.)
} 
tel'ný, a preto ho odmietli uposlúchnut'. Iný spôsob zvolil Medzinárodný súdny tribunál, ktorý naopak vyzýval páchatel'ov vojnových zločinov, aby uznali svoju vinu a prejavili l'útost' výmenou za zníženie trestu. Dôraz sa kládol na priznanie vinníkov, takže prokurátor už nemusel dokazovat' vinu. Hazan z toho vyvodzuje, že odpustenie, ak sa správne používa, predstavuje účinný politický a diplomatický nástroj. Podl'a neho nielenže môže zmenit' vzt'ah s poškodenou komunitou, ale má svoj podiel aj na redefinovaní národných hodnôt a étosu (Hazan 2012, 90). Faktom však je, že v prípade Komisie pre pravdu a zmierenie páchatelia zločinov nemuseli prejavit' nijakú lútost', ba komisie dokonca ani nečakali, že obete týmto páchatel’om odpustia. Popri tejto výhrade treba zdôraznit', že odpustenie nemôže byt' vecou štátnej inštitúcie a nemôže byt' obeti nanútené zvonka, pokial' sa nemá spreneverit' vlastnému zmyslu ako výnimočnému osobnému aktu.

\section{Odmietnutie politickej hodnoty odpustenia}

Predstava odpustenia ako politického gesta vyvolala silné námietky už v prvých desat'ročiach po druhej svetovej vojne, ked' požiadavka obnovit' spoločenské pomery v krajinách, ktoré sa vymaňovali z vojnovej katastrofy, narážala na nevyhnutnost' vyrovnat' sa s vojnovými zločinmi, osobitne so zločinom holokaustu, medzinárodne právne kvalifikovaným ako zločin proti l'udskosti. Predstavu o politickej hodnote odpustenia dodnes spochybňuje otázka: Čo sa stane s etickou dimenziou odpustenia, kam sa posunie jeho zmysel, ak toto odpustenie začleníme do politiky? R. Chaouad, poučený Derridovou kritikou účelového odpustenia, upozorňuje, že hoci svetová geopolitická scéna po druhej svetovej vojne aj so zločinmi, ktoré boli v nej spáchané, vstúpila do éry odpustenia, systematizácia odkazu na odpustenie ako spôsob riadenia situácií politického postnásilia predsa len riskuje, že sa tento zdroj vyčerpá, ba dokonca že sa zruší výnimočný, jedinečný a udalostný charakter odpustenia. Pripomína tiež, že opakovaním by sa odpustenie mohlo zmenit' na banálny akt, čo by viedlo k zabudnutiu na to, že časový horizont odpustenia nemožno zamieňat's prítomnost'ou právneho a politického poriadku, vyplývajúceho z dohody alebo zmluvy (Chaouad 2012, 53).

Proti použitiu slova odpustenie v spojení politické odpustenie otvorene namieta aj D. Rondeauová. Jej výhrady sú dvojakého druhu: jednak konceptuálne a jednak sémantické. Konceptuálny problém tkvie v tom, že začlenením odpustenia do politiky sa menia jeho základné rysy. Pritom definícia pojmu odpustenie vylučuje možnost' jeho inštrumentalizovania, jeho účelového využívania. Išlo by totiž o rozpor s ,hyperbolickou“ etikou, v rámci ktorej odpustenie má byt' bezodplatným darom obete vinníkovi. Sémantické pochybnosti súvisia so samotným výrazom politika odpustenia. Tento výraz sa v skutočnosti používa na označenie aktov ospravedlnenia, respektíve 
žiadostí o odpustenie zo strany vinníka. Nejde teda o samo odpustenie, pretože to prináleží len obeti. Ťažkost', ako ju vidí D. Rondeauová, spočíva v nasledovnom: „Výraz politika odpustenia, tým, že trvá na slove odpustenie, ponecháva celú váhu kolektívneho zmierenia na osobách, od ktorých sa očakáva odpustenie, akoby od nich závisel osud národa. Vyvíja teda neprimeraný nátlak na obete namiesto toho, aby sa prezentoval ako etická požiadavka adresovaná bývalým katom“ (Rondeau 2017, 74).

Chaouad aj Rondeauová uznávajú, že politiky odpustenia odpovedajú na pragmatický imperatív zmierenia. No analýza tých istých príkladov, na aké sa odvolávajú zástancovia idey politického odpustenia (Komisia pre pravdu a zmierenie v Juhoafrickej republike a inde), ich privádza $\mathrm{k}$ opačným záverom, pokial' ide o rolu odpustenia $\mathrm{v}$ politike. Totiž aj ked' sa tieto dva poriadky, poriadok odpustenia a poriadok zmierenia, $\mathrm{v}$ rámci politík smerujúcich $\mathrm{k}$ obnoveniu sociálneho zmieru a koexistencie obyvatel'stva po podstúpenom kolektívnom násilí zdajú byt' spojené, treba uznat' argument Chaouada, že štruktúra „logiky“ odpustenia nemôže splývat' s politickou a právnou logikou, ktorá je činná pri zmierovacích procesoch. Problémom by bolo nielen znejasnenie pojmu odpustenia, ale aj fakt, že začlenením do politického a právneho kontextu by sa odpustenie stalo synonymom beztrestnosti a nespravodlivosti. Uplatnit' na zločincov amnestiu ako domnelú formu odpustenia znamená zrieknut' sa výkonu spravodlivosti a dopustit' sa d’alšej neprávosti na obetiach zneuznaním ich práv a vymazaním pamäti v súvislosti s minulými zločinmi. Obete majú právo žiadat' potrestanie páchatel’ov a nápravu ujmy, ktorú utrpeli, a to bez ohl'adu na to, či sa napokon odhodlajú osobne odpustit' zločincovi, ktorý im spôsobil utrpenie.

Odmietnutie myšlienky odpustenia ako politického gesta vyúst’uje do záveru, že v procesoch hl’adania východiska zo situácií politického a vojnového násilia nehrá prioritnú rolu odpustenie, ale dôležité sú iné politické nástroje: ide skôr o politiky odškodnenia, respektíve zmierenia, a nie o politiky odpustenia. Inými slovami to znamená, že javy, ktoré sú svojou povahou rozdielne, nemožno merat' jedným metrom. Významovo celkom odlišné pojmy ako zmierenie, reparácia, amnestia nemožno subsumovat' pod pojem odpustenia. No nad’alej zostáva otvorená otázka: Ako obnovit' spolužitie po kolektívne spáchaných zločinoch? Totiž retributívna spravodlivost', ktorá vždy individualizuje vinu, naráža na svoje limity v prípadoch, ked’ zločiny boli spáchané kolektívne, a to nielen pokial' ide o možnost' stíhat' všetkých páchatel’ov, ale aj pokial' ide o zastavenie reprodukovania kolektívneho násilia v inej forme.

\section{Existuje aj iná alternatíva?}

V rámci spektra názorov, týkajúcich sa otázky politického odpustenia ako východiska z konfliktnej minulosti , sa objavili prístupy, ktoré možno s istou dávkou intelektuálnej odvahy označit' za alternatívu voči nesúhlasným stanoviskám, ako aj voči agilnej 
obhajobe odpustenia ako politického aktu. Tieto prístupy na jednej strane odmietajú možnost' urobit' z odpustenia minulých zločinov politickú požiadavku. Zdielajú obavu, že včlenením do politiky by sa zmysel odpustenia prekrútil a podkopal by rozhodujúce miesto spravodlivosti. Politická sféra je najprv štruktúrovaná požiadavkou spravodlivosti (Valadier 2004, 71), a preto nie je možné nič také ako politické odpustenie, ktoré by ako nejaký deus ex machina mohlo vymazat' nenávist' a vykúpit' spáchané zločiny (Lefranc 2002, 346). Odmietnutie politického inštitucionalizovania odpustenia tu ide ruka v ruke s odmietnutím prípadnej zámeny odpustenia s amnestiou, so zmierením, ba aj s lustráciou. ${ }^{8}$ Totiž aj spôsob mimosúdneho „očistenia“, akým sú lustrácie, by niekoho mohol zvádzat' $\mathrm{k}$ tomu, aby mu pripísal význam odpustenia a to v prípade, ked' výsledok lustrovania dotknutej osoby bol negatívny.

$\mathrm{Na}$ druhej strane tieto prístupy neprehliadajú fakt, že politická realita, zat’ažená neodpustitel'ným a v reakcii na to zlobou a nevraživost'ou, ktorú toto neodpustitel'né nad'alej živí vnútri spoločnosti aj navonok, si vynútila vynájst' nové formy politického stabilizovania spoločnosti po prekonaných konfliktoch. Upozorňujú na to, že včlenenie rétoriky odpustenia do oblasti politiky nie je náhodné: odhal'uje „nedostatočnost' mechanizmov pripísania zodpovednosti politickej a právnej povahy“ (Lefranc 2002, 349 - 350) a podnecuje premýšl'anie o inej zodpovednosti, vtelenej do prechodovej spravodlivosti. Jadrom týchto prístupov je poukázanie na to, že myšlienka odpustenia má moc zabránit' spravodlivosti v návrate do sveta pomsty, najmä pokial' ide o jej rigidnost', tvrdost' zákona voči slabým. Aspekt rozlišovania medzi rigoróznou spravodlivostou a zmyslom pre spravodlivost' nachádzame tak u P. Valadiera, ako aj v prácach Sandrine Lefrancovej.

S. Lefrancová si uvedomuje, že ak sa „politické odpustenie“ - akokol'vek sa spojenie týchto termínov zdá absurdné - stáva dominantnou témou debát o spravodlivosti, znamená to, že od politík inšpirovaných myšlienkou odpustenia sa predsa len niečo očakáva (pozri Lefranc 2005, 51). Inými slovami, problém ako sa vyrovnat' s minulost’ou štátneho násilia nezmizol s politikou vsádzajúcou na bežnú spravodlivost's jej individualizujúcim prístupom, teda s uplatnením trestných sankcií proti individuálnym páchatel'om zločinov. Z nášho hl'adiska je zaujímavé, že Lefrancová $\mathrm{v}$ tejto súvislosti hl'adá oporu vo filozofických textoch o odpustení, ktoré sa objavili po holokauste. Všíma si, že výraz politika odpustenia neoznačuje len politické prostriedky, ktoré využívajú vlády, respektíve medzinárodné organizácie ako nástroj na

\footnotetext{
${ }^{8}$ Na možnú zámenu odpustenia s lustráciou upozornil P. Valadier (Valadier 2004, 71), pričom ide o postreh, ktorý je obzvlášt' povšimnutiahodný v našom politickom kontexte. Lustrácie (pôvodne znamenajúce ceremóniu očistenia v starom Ríme) nadobudli svoj špecifický význam administratívnych bezpečnostných previerok osôb v niektorých postkomunistických európskych krajinách, kde viedli $\mathrm{k}$ vylúčeniu $\mathrm{z}$ verejných a politických funkcií tých, ktorí boli súčast'ou vedenia štátu a jeho represívnych zložiek.
} 
ukončenie konfliktu medzi obet’ami a ich trýznitel'mi na upokojenie sporov o minulost'. Tento výraz v sebe odráža aj filozofický problém, ktorý vznikol z konfrontácie dvoch podôb odpustenia: ,pravého“ odpustenia, teda odpustenia zbaveného akéhokolvvek postranného úmyslu, a odpustenia s podmienkami. A hoci by sme texty Jankélévitcha, Derridu a iných mohli čítat' výlučne optikou zvýrazňujúcou v nich „„čistý“ pojem odpustenia, vytvorený z kategorických fragmentov teológie a morálnej filozofie, v porovnaní s ktorými sa vládne politiky odpustenia môžu javit’ ako „hanebné kompromisníctvo“, Lefrancová túto optiku nepokladá za samozrejmú. Naopak, vyzýva, aby sme vo filozofických a sociologických reflexiách o odpustení, zrodených po druhej svetovej vojne, hl'adali také vymedzenie odpustenia, ktoré by bolo schopné objasnit' formy jeho použitia $\mathrm{v}$ momente prechodu štátov $\mathrm{k}$ demokracii, a nie jeho fixný a pravý zmysel, ktorý by mal slúžit' ako ich meradlo (Lefranc 2002, 17).

Návrh S. Lefrancovej pokladáme za cenný preto, lebo vnáša do hry dôležitý argument na podporu myšlienky nepriameho, symbolického vplyvu odpustenia v politike bez toho, aby sa odpustenie inštrumentalizovalo. Totiž debaty o odpustení v politike podl'a našej mienky niekedy zostávajú visiet' medzi dvoma krajnost'ami - bud' redukujú odpustenie na účelový politický, respektíve inštitucionálny nástroj, čím ho menia na jednoduchú politickú či diplomatickú stratégiu; alebo uzatvárajú odpustenie do sféry hyperbolickej etiky, čím spochybňujú možnost', že by myšlienka odpustenia mala mat' reálny dosah na oblast' l’udských záležitostí. Postačí však vrátit' sa $\mathrm{k}$ argumentácii obiahnutej v dnes už referenčných textoch o odpustení, zrodených $\mathrm{v}$ desat'ročiach po holokauste, aby sme pochopili, prečo výzva odpútat' sa od fixného zmyslu pojmu odpustenie má svoj dobrý raison d'être. V Jankélévitchovej eseji Odpustenie nájdeme indíciu, podl'a ktorej odpustenie sa môže stat' zdrojom inšpirácie pre „inú“ ako rigoróznu spravodlivost' tam, kde nepostačuje bežná spravodlivost' so svojimi sankciami. „Odpustenie v skutočnosti náleží do mimozákonnej, mimoprávnej oblasti našej existencie; tak ako spravodlivost', a ešte viac než ona, je otvorením uzavretej morálky, je akousi aureolou obklopujúcou striktný zákon: neporušujeme niekedy úmyselne pravidlá prísnej spravodlivosti, aby sme zostali spravodliví?“ (Jankélévitch 1967, 16; čes. 1996, 14). Aj Derrida v rozhovore Storočie a odpustenie si všíma túto zvláštnost' práva, ked' na jednej strane zdôrazňuje neredukovatel’nost' „hyperbolickej“ vízie odpustenia (teda odpustenia rámcovaného etikou „nadmiery“, bezodplatnosti) na realitu pragmatických procesov zmierenia, no na druhej strane uznáva ich neoddelitel'nost'. A to v tom zmysle, že hyperbolická etická vízia odpustenia sa pokladá za akýsi referenčný horizont, inšpirujúci zodpovedné rozhodovanie na poli politiky a práva. „Aby sme mohli ovplyvnit' politiku či to, čo ste nazvali pragmatické procesy, aby sme zmenili právo (ktoré sa teda nachádza medzi dvoma pólmi, ideálnym a empirickým..., treba sa odvolávat' na to, čo ste práve nazvali hyperbolickou etickou víziou 
odpustenia. ... len táto neochvejná požiadavka môže usmerňovat' dejiny zákonov, evolúciu práva“" (Derrida, 2001, 125; čes. 2003, 120). K tomuto myšlienkovému prúdu sa svojou pozíciou prihlasuje aj S. Lefrancová. Z jej úvah vyplýva, že odpustenie je význačným motívom debát o prechodovej spravodlivosti preto, lebo po holokauste sme konfrontovaní s neodpustitel'ným, teda s neodčinitel'nými zločinmi, ktorých pôvodcovia konali ako zástupcovia štátu a ktorých obete často neprežili. V tomto kontexte vznikajú nielen otázky, kto by mal odpustit' alebo či na spoločenské zmierenie postačuje bežná spravodlivost', ale aj otázka politickej zodpovednosti štátu. Pre zástancov odpustenia ako politického inštrumentu na riešenie konfliktov je to zároveň podnet, aby zvážili nielen argumenty odmietajúce uznat' odpustenie za politickú cnost', ale aj tie, ktoré síce nie sú proti inšpirovaniu politiky jazykom odpustenia, ale trvajú na tom, aby sa politika a odpustenie chápali ako dva nezávislé poriadky.

\section{Záver}

Vrát'me sa $\mathrm{k}$ otázke $\mathrm{v}$ názve tohto článku: Je odpustenie $\mathrm{v}$ politike realitou, alebo ilúziou? Nazdávame sa, že je realitou, pokial’ týmto výrazom mienime teoretický diskurz, týkajúci sa tejto otázky (ktorý má nepochybne svoju dynamiku a význam); takisto je realitou, pokial' ním máme na mysli politickú rétoriku, ktorá sa inšpiruje „jazykom“ odpustenia. Presnejší termín pre túto politiku by však bol politika ospravedlnenia. Jej význam netreba podceňovat', hlavne pokial' ide o prevzatie časti politickej zodpovednosti za minulé zločiny. No jedným dychom sa žiada dodat', že verejné prejavy empatie zo strany politikov nezriedka čelia nástojčivej otázke, či sú úprimné a či nejde len o politické „divadlo“ na vyvolanie sympatií verejnosti a získanie politických bodov. Myšlienkou odpustenia sa inšpirovali aj politiky prechodovej spravodlivosti s jej mimosúdnymi inštitúciami, akými v devät'desiatych rokoch minulého storočia boli Komisie pre pravdu a zmierenie. Ani tu však nešlo o pravé odpustenie. Derrida upozornil, že „status Komisie pre pravdu a zmierenie je v tomto ohl'ade dost' nejednoznačný, rovnako ako diskurz Tutuho, ktorý osciluje medzi netrestnou a ne-právnou logikou odpustenia (hovorí jej obnovijúca) a súdnou logikou amnestie“" (Derrida 2003, 117; čes. 2003, 112). Napokon, niečo ako „duch odpustenia“ možno zaregistrovat' aj v rovine trestnej spravodlivosti, aj ked” nie v podobe inštitucionálneho odpustenia. Tento moment si okrem Jankélévitcha a Derridu všimol aj Ricœur, ktorý v súvislosti s inštitúciami hovoril o akomsi „tajnom odpusteni'“ (fr. l' incognito pardon) (Ricoeur 2000, 594). Nemal tým na mysli inštitucionalizovanie odpustenia, pretože inštitúcie musia zostat' verné svojim záväzkom. Poukázal však na to, že súdy neponechávajú vinníka úplne napospas jeho 
vine ani vtedy, ked' spravodlivost' vylučuje možnost' odpustenia. Myšlienka „tajného odpustenia“ má byt' len potvrdením toho, že aj vinníkovi, hoci je trestne stíhaný, prináleží vážnost', tak ako každému človeku.

Paralelný systém restoratívnej (obnovujúcej) spravodlivosti, vynájdený na to, aby sa dôraz presunul na obete, na ich práva a ich odškodnenie, na manifestovanie bolesti obetí pred páchatel'om zoči-voči v mimosúdnych vypočutiach, a aby pohol páchatel'ov uznat' svoju zodpovednost' za spáchané zločiny a prejavit' l'útost', ktorá by obetiam pomohla zmiernit' ich utrpenie, je nepochybne užitočnou inštitúciou. Je však ilúziou spoliehat' sa na možnost' priameho prenesenia odpustenia do roviny politiky alebo na možný prospech z takej inštitucionálnej formy kvázi odpustenia, akou je amnestia. A to nielen pre neprípustnost' zámeny odpustenia s niečím, čím toto odpustenie nie je a nemôže byt' (povedzme s politikou sankcií, či už trestných alebo peňažných, s politikou ospravedlnenia alebo s politikou zmierenia či priamo s politickou inštitúciou amnestie), ale aj z iného dôvodu. Totiž prístup, ktorý počíta s tým, že odpustenie sa dá politicky „riadit““, teda že ho možno inštrumentalizovat', využívat' na ciele, ktoré sa naň nabal'ujú zvonka, sa podl'a našej mienky zakladá na chybnej logike. Predpokladá totiž, že možno hrat' na dvoch stoloch súčasne: sledovat' kolektívny, politický účel odpustenia (napríklad zmierenie medzi znepriatelenými skupinami), no zároveň chciet', aby si odpustenie aj na pôde politiky ako sféry kolektívnych mocenských vzt’ahov podržalo svoju zvláštnu povahu a intersubjektívne viazaný zmysel.

Odpustenie ex definitione je vzt'ah, ktorý sa týka dvoch osôb - urazeného a urážajúceho, obete a vinníka. Obet' nemožno z tohto vzt'ahu vyňat', odsunút', ani ju v ňom nahradit' nejakou nadosobnou kolektívnou inštanciou, na ktorú by mohlo byt' delegované právo odpustit' páchatel'om kolektívne spáchaných zločinov. Skutočné odpustenie preto nemôže byt' politickým aktom. Ide o mimopolitický a mimoprávny vzt’ah. Explicitným svedectvom je prípad ženy, obete apartheidu, ktorá odmietla odpustit', pričom svoje odmietnutie odôvodnila tým, že na to nie je pripravená. Derrida $\mathrm{v}$ tejto súvislosti náležite poznamenal, že ,anonymný štátny orgán alebo verejná inštitúcia nemôžu odpúšt'at'. Nemajú na to ani právo, ani moc; okrem toho by to nemalo nijaký zmysel. Zástupca štátu môže súdit', no presne vzaté, odpustenie nemá so súdnym rozhodnutím nič spoločné. Dokonca ani s verejným alebo politickým priestorom“" (Derrida 2001, 118; čes. 2003, 113).

Odpúšt’ajúci neodpúšt'a vinu, ale odpúšt’a vinníkovi, pričom pamät' na zločin sa tým nevymazáva. V tom je rozdiel medzi odpustením a politicky využívanou amnestiou, ktorá vnútením svojho jazyka vedie $\mathrm{k}$ amnézii, $\mathrm{k}$ zabudnutiu na zločiny v mene „vyššieho“ záujmu, ale na úkor obetí. Vždy sa tu vynára otázka, akú cenu 
zaplatí spoločnost' za „politické riadenie“ odpustenia, nech už by jeho ciel” bol akokol'vek ušl'achtilý. Iste, je tu aspekt, na ktorý upozornil P. Sucharek - moment kríženia a vzájomných, hoci paradoxných praktických súvislostí odpustenia a zmierenia: „Ked' začneme hovorit' o odpustení ako o udalosti, musíme túto udalost' ukotvit' v účelovej praxi zmierenia; ked' vyjasňujeme štruktúru zmierenia, môžeme jeho racionalitu podržat' jedine $\mathrm{v}$ kontexte paradoxu odpustenia. Začat' v praxi $\mathrm{s}$ jedným znamená príst' k druhému a naopak“ (Sucharek 2017, 425). No vo vzt’ahu k politickému zmiereniu toto tvrdenie neplatí. Politické zmierenie je dlhodobý proces, zatial' čo odpustenie ako udalost' medzi dvoma osobami je oddelené od politických ciel'ov. Pripustit', aby sa tieto dve roviny - rovina odpustenia ako medziosobného vzt’ahu a politický proces zmierenia - zliali do nerozlíšitel'ného celku (povedzme s úmyslom mravne povzniest' politiku), znamená inštrumentalizovat' odpustenie čiže popriet' tak nielen princíp spravodlivosti, ale aj zásadu, ktorá odpusteniu dáva skutočný zmysel: jedine obet' je povolaná na to, aby odpustila.

\section{Literatúra}

ARENDT, H. (2012): L'humaine condition. Paris: Gallimard.

CAUSSE, G. (2016): Le pardon, un geste politique? Nouvelle revue théologique, 138 (2), 257 - 272.

DERRIDA, J. (2001): Foi et savoir suivi de Siècle et le pardon (entretien avec Michel Wieviorka). Paris: Éditions du Seuil.

DERRIDA, J. (2003): Vira a vědení. Století a odpuštění (Rozhovor Michela Wieviorky s Jacquesem Derridou). Přeložil Pavel Bartošek. Praha: Mladá fronta.

DERRIDA, J.(2005): Pardonner: l'impardonnable et l'imprescriptible. Paris: L' Herne.

HAZAN, P.: (2012): La realpolitik du paron. Révue internationale et stratégique, 4 (88), 81 - 90. DOI: https://doi.org/10.3917/ris.088.0081

CHAOUAD, R. (2012): Le temps du pardon. Révue internationale et stratégique, 4 (88), 49 - 57. DOI: https://doi.org/10.3917/ris.088.0049

JANKÉLÉVITCH, V. (1967): Le pardon. Paris: Aubier-Montaigne.

JANKÉLÉVITCH, V. (1986): L'imprescriptible. Paris: Éditions du Seuil.

JANKÉLÉVITCH, V. (1996): Odpuštěni. Přeložil Zdeněk Kouřím. Praha: Mladá fronta.

LECOMTE, J. (2012): La justice restauratrice. Revue du MAUSS, 2 (40), 223 - 235. DOI: https://doi.org/10.3917/rdm.040.0223

LEFRANC, S. (2002): Politiques du pardon. Paris: Presses Universitaires de France.

LEFRANC, S. (2005): Qu'attendre des politiques du pardon? In: Labelle, M., Antonius, R., Leroux, G. (sous la dir.): Le devoir de mémoire et les politiques du pardon. Québec: Presses de l'Université du Québec.

LÉVY, D. J. (1993): Politický řád. Přeložily Libuše Měkutová a Jana Ogrocká. Praha: Slon.

RICEUR, P. (1995): Le juste. Paris: Éditions Esprit.

RICCEUR, P. (2000): La mémoire, l'histoire, l'oubli. Paris: Éditions du Seuil.

RONDEAU, D. (2017): Du pardon éthique au pardon politique: instrumentalisation ou élargissement du pardon? Revue GenObs, 1 (2), 72 - 99. Dostupné na: file:///C:/Users/edite/Downloads/149-Article\%20Text-354-1-10-20170803.pdf (Navštívené 23. 4. 2020).

SUCHAREK, P. (2017): Zmierenie nie je odpustenie. Chvála odpustenia. Filozofia, 72 (6), 417 - 428. 
VALADIER, P. (2004): Le pardon en politique. Revue Projet, 4 (281), 67 - 72. DOI: https://doi.org/10.3917/pro.281.0067

TURGLS, N. (2015): La justice transitionnelle, un concept discuté. Les cahiers de la justice, 3 (3), $333-342$.

UDOFF, A. (ed.) (2013): Vladimir Jankélévitch and the Question of Forgiveness. Lanham: Lexington Books.

Táto práca vznikla v rámci projektu VEGA 2/0049/20 K idei l’udských práv-koncepty, problémy, perspektivy.

Dagmar Smreková

Filozofický ústav SAV

Klemensova 1

81364 Bratislava 1

Slovenská republika

e-mail: dagmars1@seznam.cz

ORCID ID: https://orcid.org/0000-0001-6946-0134 